\title{
Сергій Нехаснко,
}

Національний університет оборони України імені Івана Черняховського ORCID ID 0000-0003-0112-1018

DOI 10.33099/2617-1775/2019-01/185-196

\section{ПРОФЕСІЙНА КОМПЕТЕНТНІСТЬ ОРГАНІЗАТОРІВ МОРАЛЬНО- ПСИХОЛОГІЧНОГО ЗАБЕЗПЕЧЕННЯ: ПОНЯТТЯ, ЗМІСТ І СТРУКТУРА}

У статті розглянуто питання щзодо змісту професійної компетентності організатора морально-психологічного забезпечення. 3'ясовано сутність ключових понять "зміст" $і$ "структура", визначено та науково обгрунтовано основні компоненти професійної компетентності, а саме такі: иіннісно-мотиваційний, змістовий, діяльнісний і суб'єктний. Ïх змістове наповнення включає цінності, мотиви, інтереси та потреби; відображає систему компетентнісно орієнтовних знань; визначає п'ять груп взаємопов'язаних здатностей - гностичні, проектувальні, конструктивні, комунікативні, організаторські; розкривто систему професійно важливих якостей.

Ключові слова: морально-психологічне забезпечення; професійна компетентність; організатори морально-психологічного забезпечення; цінності; мотивачія; мотиви; інтереси; потреби; професійно важливі якості; знання; здатності.

Постановка проблеми. Підготовка та комплектування Збройних сил (3С) України офіцерами структур морально-психологічного забезпечення (МПЗ) нині $\epsilon$ одним із найважливіших і найскладніших проблем сучасної військової освіти. Така ситуація актуалізує роль післядипломної освіти у розвитку, а інколи й формуванні, професійної компетентності офіцерських кадрів, зокрема, який відповідає за організацію морально-психологічного забезпечення у військовій частині (підрозділі). Від якості їх професійної дії залежить реалізація відповідних завдань, які зумовлені цим видом забезпечення. Організатор морально-психологічного забезпечення - це фахівець, який займається навчально-виховною (педагогічною) та психологічною роботою у військах. Це накладає на нього велику відповідальність як за зміст і результати власної професійної діяльності, так і за поведінку та результати діяльності вихованців. У результаті врахування специфіки військово-професійної діяльності та функціональних обов'язків кожен офіцер структур з морально-психологічного забезпечення водночас $є$ вихователем і психологом. Сфера їх діяльності носить гуманітарний характер i, як результат, вимагає більш творчого підходу до виконання завдань, загального бачення ситуації та великої частки ситуативності у вирішенні службових і фахових завдань.

3 огляду на те, що усі вищезазначені обставини висувають суворі вимоги до виконання завдань морально-психологічного забезпечення у всіх аспектах дій військ (сил) i, як результат, до професійної підготовки офіцерів структур морально-психологічного забезпечення оперативно-тактичного рівня, a ïx професійна характеристика не визначена у нормативно-правових документах, виникла необхідність у визначенні змістової структури професійної компетентності. 
Аналіз останніх досліджень i публікацій. Проблема формування професійної компетентності та їі структури досить актуальна та стала об'єктом дискусій і досліджень різних наукових галузей XX -XXI ст., що збагатило їхню джерельну базу потужним арсеналом праць.

Розв'язання проблеми розвитку професійної компетентності фахівців важливим теоретичним підгрунтям $\epsilon$ результати наукових досліджень 3 проблеми філософії освіти В. Андрущенка, І. Зязюна, В. Кременя, В. Лутая та ін; проблеми компетентісного підходу в освіті (В. Байденко, А. Вітченко, М. Головань, О. Дубасенюк, Г. Єльнікова, Е. Зеєр, І. Зимня, А. Каленський, Н. Кузьміна, Н. Ничкало, О. Пометун, Дж. Равен, В. Свистун, А. Субетто, А. Хуторськой, В. Ягупов та ін.). Актуальні проблеми військової освіти стали центром уваги О. Барабанщикова, М. Варія, В. Вдовюка, О. Діденка, А. Зельницького, Д. Іщенка, А. Лігоцького, М. Нещадима, Ю. Приходька, В. Стасюка, В. Телелима, В. Ягупова та ін.

Важливими для нашого дослідження $\epsilon$ положення про формування психолого-педагогічної, діагностичної, управлінської та інших видів компетентності, що висвітлені в працях В. Адольфа, В. Байденка, О. Гури, Н. Кузьміної, А. Маркової, В. Свистун, С. Сисоєвої, Ю. Татура, Л. Тархана та iн.

Теоретичні аспекти реалізації компетентісного підходу при підготовці військових фахівців 3 вищою освітою висвітлені у працях А. Вітченка, А. Зельницького, В. Осьодла, І. Чистовської, В. Ягупова та ін. Теоретичні та методичні аспекти формування фахової компетентності у закладах вищої освіти розкрито у працях Г. Єльнікової, О. Зайченка, В. Маслова, О. Тімець та ін.

Дослідженню педагогічних умов підготовки військовослужбовців до професійної діяльності присвячена низка дисертацій (Г. Артюшин, Т. Ваколюк, О. Діденко, Ю. Захарчишина, А. Литвин, А. Радванський, І. Сніцар, К. Тушко, В. Уліч та ін.); наукові основи впровадження в освітній процес закладів вищої освіти дистанційного навчання розкрито в розвідках О. Андрєєва, В. Баркасі, В. Бикова, І. Блощинського, В. Кухаренка, М. Мартиненко, Р. Миколайчука, П. Стефаненка та ін.

У результаті здійснення наукового пошуку виявили різноманітні комбінації основних компонентів професійної компетентності педагога, які характеризують іiі зміст. Серед них, найбільш уживаними, на нашу думку, $\epsilon$ такі: мотиваційна, когнітивна, змістова, особистісна, ціннісна, рефлексивна тощо. Однак у наукових роботах досить часто зустрічаються й компоненти, подібні за змістовим значенням, які мають іншу або доповнену більш розширену назву, наприклад:

мотиваційний - мотиваційно-ціннісний, поведінковий;

комунікативний - інформаційний, соціально-комунікативний та інші.

Звертаємо увагу на те, що проблема професійної компетентності офіцеріворганізаторів МПЗ у наукових розробках не була виявлена.

Мета статті: обгрунтувати професійну компетентність організаторів морально-психологічного забезпечення. 
Виклад основного матеріалу. Морально-психологічне забезпечення підготовки та ведення бойових дій - один із основних видів всебічного забезпечення військ (сил), метою якого є формування та підтримка моральнопсихологічного стану (МПС) особового складу, його професійно важливих, бойових і психічних якостей, необхідних для успішного виконання ним бойових завдань. За будь-яких обставин і умов бойових дій МПЗ має проводитись комплексно, безперервно, цілеспрямовано, і чим складніша та напруженіша обстановка, тим активніше, цілеспрямованіше та конкретніше.

Ефективне проведення МПЗ передбачає своєчасне цілеспрямоване професійне використання всіх наявних сил і засобів для попередження негативних змін МПС особового складу, перерозподіл зусиль і посилення впливу на певних напрямках роботи.

На сучасному етапі розвитку суспільства продуктивність професійної діяльності залежить не стільки від володіння будь-якою заданою спеціальною інформацією, скільки від уміння орієнтуватися в інформаційних потоках, вирішувати проблеми, отримувати i використовувати нові знання й інші ресурси для досягнення поставленої мети, ступеня ініціативності та відповідальності. Мало бути хорошим співробітником, необхідно бути професіоналом своєї справи - ініціативним, здатним приймати рішення в ситуаціях невизначеності та брати на себе відповідальність. Це неможливе без володіння професійними та фаховими знаннями та здатностями на планетарному, а не вузькоспеціальному рівні, без наявності творчоінноваційних, ціннісно-орієнтаційних і діалогічно-комунікаційних якостей. На думку провідних вітчизняних фахівців-педагогів, нині орієнтування освіти виключно на академічні й енциклопедичні знання випускників застаріло 3 точки зору нових вимог.

Сучасна військова освіта має бути націленою на формування у випускника його професійної компетентності. Це підкреслюється новими завданнями, які ставить держава перед вищою освітою, оскільки саме їй належить провідна роль у формуванні культурних цінностей особистості взагалі та фахівця, зокрема, зростанні наукового та інтелектуального потенціалу країни [1]. Відповідно ці вимоги викладені, у законах України і державних програмах [2, 3].

3 іншого боку одним із найбільш важливих факторів впливу на підготовку військового фахівця є вимоги, які обумовлені особливостями сучасних війн та збройних конфліктів. Зміст і особливості сучасної війни, ії надзвичайно висока морально-психологічна насиченість передбачають високу громадянську свідомість, всебічну морально-психічну стійкість і готовність воїнів виконання поставлених бойових завдань [4]. Військова-професійна компетентність, яку у процесі професійної підготовки на етапі оперативно-тактичної підготовки має розвивати (інколи, на жаль, і формувати) організатор морально-психологічного забезпечення. Формально вимоги до неї прописані в професійному стандарті 
офіцера оперативно-тактичного рівня Збройних сил України 3 моральнопсихологічного забезпечення.

Таким чином, головна вимога, яка пред'являється до майбутнього організатора МПЗ, - це здатність оперативно та професійно розв'язувати посадові компетенції як офіцерові та фахівцю на оперативно-тактичній ланці управління. Їх професійний розвиток передбачає формування власних професійних позицій, самостійності та організованості, вміння свідомо планувати свої дії відповідно до, з одного боку, внутрішніх переконань i цінностей, а з іншого - в межах посадових компетенцій.

Зважаючи на вищеозначене, відповідно до сучасних вимог державних освітніх стандартів до випускників Національного університету оборони України імені Івана Черняховського (Національної рамки кваліфікації, освітньо-професійних програм тощо), а також тенденцій розвитку освіти у світі фахова підготовка організаторів МПЗ грунтується на компетентному підході.

Реалізація в системі військової освіти компетентнісного підходу до підготовки організаторів МПЗ вимагає всебічного з'ясування основних аспектів даного явища. У категорійно-поняттєвий апарат вітчизняної педагогіки поняття «компетентність» увійшло порівняно недавно. Його застосування актуалізується запровадженням компетентнісно-орієнтованого підходу у стандартах вищої освіти. Поняття «компетентність» також широко застосовуються у науковому обговоренні проблем вищої освіти. Нині відбувається осмислення та обговорення у наукових співтовариствах, що $\epsilon$ компетентність, ii зміст, способи іiі формування, розвиту та оцінювання. Відбувається постійна дискусія щодо уточнення цього поняття. Відповідно тому, нині не сформовано єдиної думки щодо визначення поняття «компетентність» і трактування його змісту.

Для визначення професійної компетентності організатора МПЗ необхідно 3'ясувати сутність поняття «компетентність». Враховуючи його іноземне походження, для визначення звернулися до словників іноземних мов, у яких компетентність тлумачиться як 1) «володіння знаннями, які дозволяють судити про що-небудь, висловлювати вагому, авторитетну думку» [5, с. 315]; 2) «поінформованість, обізнаність, авторитетність» [6, с. 282].

У словнику української мови компетентний - це той, хто «має достатні знання в якій-небудь галузі, 3 чим-небудь добре обізнаний, тямучий, грунтується на знанні, кваліфікований» [7, с. 250].

У психолого-педагогічній літературі зустрічається велика кількість різновидів компетентності залежно від специфіки діяльності фахівця. Зокрема, дослідники виокремлюють такі види компетентності: професійна, педагогічна, фахова, дидактична, методична, комунікативна, психологічна, соціокультурна, управлінська, конфліктологічна, політична, діагностична, міжкультурна, економічна, гендерна, інформаційна тощо. У контексті нашого дослідження інтерес представляють професійна компетентність, зокрема фахова компетентність організатора МПЗ. 
Важливим для нас $є$ визначення поняття «професійна компетентність» організатора МПЗ. Аналіз наукових досліджень зі цієї проблеми дозволив нам прийти до висновку, що науковці по-різному тлумачать поняття «професійна компетентність». Проте, всі вони одностайні в тому, що професійна компетентність відображає рівень професійних знань, умінь, навичок, досвіду та професійно важливих якостей фахівця, що забезпечує виконання ним певної професійної діяльності.

Зокрема, на думку І. Зязюна, зміст професійної компетентності включає знання предмета, методики його викладання, педагогіки й психології та рівень розвитку професійної самосвідомості, індивідуально-типові особливості й професійно важливі якості [8, с. 78].

В. Ягупов під поняттям «професійна компетентність» розуміє системне інтегральне явище щодо суб'єкта професійної діяльності, що включає не тільки його професійні та фахові знання, навички, вміння, професійно важливі якості, професійний і фаховий досвід, які забезпечують успішне реалізацію посадових компетенцій, але і мотиваційну готовність і позитивне ставлення до цілей, завдань, змісту, методик, технологій, засобів і результатів своєї професійної діяльності.

В. Свистун витлумачує «професійну компетентність» як теоретичну, практичну та психологічну види підготовленості особистості майбутнього фахівця, що проявляється в його здатності та готовності до здійснення конкретного виду професійної діяльності [9, с. 186].

Таким чином, можна наголошувати, що професійна компетентність офіцера - організатора МПЗ полягає у його здатності та готовності здійснювати діяльність, спрямовану на формування та підтримання, а за необхідності та відновлення необхідного для виконання поставлених навчальних, навчальнобойових і бойових завдань МПС особового складу, що забезпечуватиме їх виконання.

Професійна компетентність офіцера - організатора МПЗ звернена, з одного боку, до його діяльності, зумовленою службовими обов'язками, а з іншого - до його підлеглих, успішне виконання завдань якими він має забезпечувати. Готуючись до організації та здійснення МПЗ, він обмірковує його мету, зміст, враховує особливості бою, суспільно-політичної обстановки, інших умов i чинників, що впливають на МПС, власні можливості. Важливою особливістю його професійної компетентності є іiі комплексність, що вимагає від нього здатності на основі наукових знань і професійного досвіду синтезувати рішення для успішного розв'язання задач МПЗ бою, аналізувати різноманітні ситуації, що зумовлюе необхідність осмислення педагогічних закономірностей та психологічної сутності явища, вибору засобів взаємодії. Розв'язання кожної педагогічної задачі актуалізує всю систему педагогічних здатностей офіцера структур МПЗ, які проявляються як єдине ціле.

Таким чином, його професійна компетентність не $є$ простою сумою засвоєних алгоритмів чи способів діяльності, адже це усвідомлена система наукових знань і здатностей, професійного досвіду, де $\epsilon$ місце власним оцінкам 
i критичним поглядам, тобто квінтесенція управлінської культури i компетентності «керівників, з одного боку, тісно пов'язані із загальною культурою особистості, загальнолюдською та професійною культурою, а система цінностей управлінської діяльності - 3 системою цінностей суспільства, конкретної професійної спільноти й особистісними цінностями керівників, а 3 іншого - представляють інтегроване професійно-важливе утворення, яке характеризує особливості системи їх управлінських знань, навичок, умінь, здатностей й актуалізується в професійній свідомості, стилі управлінської діяльності, управлінській етиці та поведінці» [10, с.300].

На основі проведеного аналізу наявних підходів до визначення змісту компетентності вважаємо, що основними компонентами професійної компетентності організаторів МПЗ є такі: цннісно-мотиваційний; емоційновольовий; когнітивний; організаційно-діяльнісний; психологічний; предметнодіяльнісний; індивідуально-психологічний; суб’єктний.

Ціннісно-мотиваційний компонент. Однією 3 основних якостей організатора МПЗ у професійній діяльності є його професійна спрямованість, що безпосередньо відображається його ставленні до свого службового призначення та мотивації реалізації посадових компетенцій. У психологічному розумінні спрямованість офіцера визначається як сукупність стійких мотивів, які орієнтують його на професійну діяльність. Ця спрямованість характеризується інтересами, схильностями, переконаннями, ідеалами, в яких виявляється світогляд офіцера та його ставлення до свого службового призначення. Розглядаючи це визначення щодо організаторів МПЗ, в нього додатково включається інтерес до вихованців, до фахової діяльності, схильність займатися нею, усвідомлення своїх здібностей і здатностей.

Він характеризується насамперед позитивним ставленням до діяльності офіцера структур МПЗ і знаходить своє відображення у внутрішній вмотивованості до своєї професійної діяльності, показниками якого $\epsilon$ професійні цінності, інтереси, потреби та мотиви набуття військовопрофесійної освіти.

Емоційно-вольовий компонент виявляється в самодетермінації й саморегуляції своєї діяльності та різних психічних процесів, здатності з власної ініціативи, виходячи 3 усвідомленої необхідності, виконувати посадові компетенції у заздалегідь спланованому напрямку, організовувати свою фахову діяльність та іiі спрямувати на виконання поставлених завдань, а також здатності зусиллям волі стримати зовнішній прояв емоцій в екстремальних умовах бойової обстановки або навіть показати зовсім протилежне.

Роль організатора МПЗ у формуванні та підтриманні МПС досить важлива і складна, що передбачає такі дії: створення умов для розвитку військового професіонала; успішну організацію МПЗ з метою формуванням у підлеглих необхідних національно-патріотичних, морально-бойових і фізичних якостей, психологічної готовності до ведення бойових дій. Він окремих прикладних завдань виконує і загальнодержавні завдання: виховання покоління громадян України, здатних ефективно працювати і вчитися продовж життя, оберігати й 
примножувати цінності національної культури та громадянського суспільства. Ïї реалізація процесі здійснення МПЗ вимагає від організатора МПЗ творчості, активності, високої психолого-педагогічної культури і наполегливої праці.

Своєю поведінкою організатор МПЗ постійно впливає на формування у підлеглих високих моральних і професійно важливих якостей. Тому не виникає сумніву, що в умовах гуманізації та демократизації військової сфери організатор МПЗ стає ключовою постаттю у педагогічному середовищі.

Когнітивний компонент. Включає інтелектуальну сферу організатора МПЗ, його загальнонаукову обізнаність та обізнаність у військово-професійній сфері та найголовніше наявність системних психолого-педагогічних знань у сфері організації МПЗ.

Для здійснення професійної діяльності офіцер структур МПЗ має володіти як професійними знаннями, так і системою фахових психолого-педагогічних знань, що складають: загальновійськові, виховні, методичні, комунікативні, управлінські, діагностичні, психологічні, дослідницькі знання.

Зміст когнітивного компонента складають: психолого-педагогічні, професійні знання, а також знання методологічних принципів дослідження проблем у сфері психологічних аспектів військово-професійної діяльності та психолого-педагогічних умов для розвитку пізнавальної мотивації та здатностей підлеглого особового складу; психологічних основ військовопрофесійної діяльності.

Позитивний результат розвитку професійних знань організатора МПЗ буде тільки в тому разі, якщо він буде успішно застосовувати їх у своїй практичній діяльності.

Предметно-діяльнісний компонент організатора МПЗ включає практичну здатність успішно виконувати свої функціональні обов'язки у процесі діяльності у військовій частині (підрозділі). Відповідно до функціональних обов'язків організатор МПЗ повинен мати наступні основні фахові здатності:

Дослідницька - здатність до діалогічного спілкування з кваліфікованими фахівцями та науковцями, аргументованого доведення власної позиції 3 досліджуваних питань.

Технологічна - ефективне здійснення комунікації 3 використанням інформаційних технологій, доведення до підлеглих наказів та розпоряджень у ході бою (операції) з використанням сучасних автоматизованих систем управління.

Управлінська - здатність зрозуміло формулювати рішення та ставити завдання підлеглим на виконання поставлених завдань, мотивувати підпорядкований особовий склад на виконання отриманих завдань, організовувати їх якісне виконання.

Організаційна - забезпечення ефективних внутрішніх комунікацій в процесі повсякденної діяльності, під час бойової підготовки, забезпечення налагодження ефективних внутрішніх комунікацій під час вищевказаних заходів, забезпечення ефективних внутрішніх комунікацій під час організації МПЗ операцій (бойових дій). 
Інформаційна - формулювання наративів, організація та здійснення інформаційного впливу на свідомість особового складу, організація інформування громадськості та представників медіа, здійснення стратегічних комунікацій, внутрішніх комунікацій під час підготовки та ведення операцій (бойових дій).

Діагностично-прогностична - здатність обгрунтовано доводити результати аналізу соціальних та суспільно-політичних явищ та процесів в суспільстві, збройних силах та військових колективах під час внутрішньокомунікаційної роботи для прийняття управлінських рішень.

Формувальна - своєчасне забезпечення посадових осіб обгрунтованою інформацією щодо рівня сформованості морально-психологічної спроможності

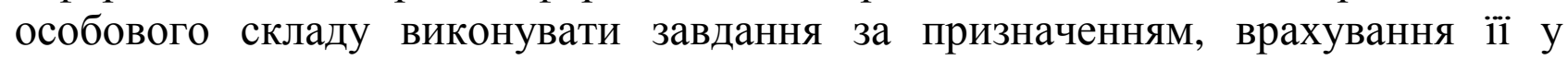
підготовці військових частин та з'єднань, виробленні замислу та прийнятті управлінських рішень щодо їх застосування та організації заходів моральнопсихологічного забезпечення.

Контрольна - забезпечення ефективних комунікацій з метою удосконалення діяльності суб'єктів МПЗ, своєчасного забезпечення командирів (начальників) систематизованою, об’єктивною інформацією щодо рівня МПС особового складу та стану суспільно-політичної обстановки в пунктах постійної дислокації (районах виконання завдань за призначенням) для прийняття управлінських рішень.

Він містить такі складові: професійні уміння та навички (здійснювати типові види педагогічної діяльності; організовувати та управляти освітніми процесами; орієнтуватися у проблемних ситуаціях; застосувати індивідуальний підхід до підлеглих; робити правильний вибір, у тому числі і в складних ситуаціях; визначати емоційний стан підлеглих, та враховувати його в освітній діяльності; використовувати передовий досвід).

Військово-професійний досвід (рівень оволодіння фахом на етапі здобування вищої військової освіти; проходження військової служби на посадах за фахом; бойовий досвід; зразкова поведінка).

Значну роль у професійній характеристиці організатора МПЗ відіграє самосвідомість, в структуру якої входить усвідомлення норм, правил, моделі діяльності, формування професійного; співвідношення себе 3 деяким професійним еталоном, ідентифікація; оцінювання себе іншими, професійнореферентними особами; самооцінка.

Організаиійно-діяльнісний компонент організатора МПЗ: - це раціональне врядування (самоврядування), ефективність менеджменту (управління МПЗ, як видом забезпечення) та самоменеджменту, умілий розподіл та використання часу та інших власних ресурсів.

Офіцер оперативно-тактичного рівня структур МПЗ має вміти: проводити дослідження складних систем воєнного призначення; застосовувати основні види наукового аналізу, добирати й корегувати систему методів, оформлювати і презентувати власні наукові здобутки відповідно до чинних вимог; здійснювати критичний аналіз та обгрунтовувати актуальні наукові питання, знаходити нові 
оригінальні шляхи та способи їх розв'язання; якісно організовувати моральнопсихологічне забезпечення підпорядкованих військових частин та підрозділів під час підготовки та ведення операцій (бойових дій).

Психологічний компонент - визначає психологічну готовність особового складу до бойових дій в умовах сучасної війни, збройного конфлікту. До психологічних якостей належать розвиненість сприйняття, уваги, мислення, пам'яті, мови; швидкість і точність реакцій; емоційно-вольова стійкість. Розвиток психологічних якостей сприяє максимально повному прояву військово-професійних знань, умінь і навичок та фізичних якостей особового складу в різних, найскладніших ситуаціях сучасного бою. Формування високої емоційно-вольової стійкості вимагає виховання у воїнів мужності, стійкості, самовладання, рішучості, готовності до саможертовності, ініціативності, цілеспрямованості тощо.

Психологічний компонент включає різноманітні психічні явища, передусім ті психічні властивості особистості, які обумовлюють суспільно значущу поведінку і діяльність людини [11, с. 17].

Індивідуально-психологічний компонент - його психологічно-вольові якості (Офіцер оперативно-тактичного рівня структур МПЗ у мирний і воєнний час зобов'язаний постійно знати бойову та суспільно-політичну обстановку, МПС особового складу, володіти технологіями та методиками їх оцінювати; вміти виробляти пропозиції з МПЗ підготовки та застосування військових частин; здійснювати планування та організовувати доведення завдань МПЗ до підлеглих; контролювати їх виконання; безперервно керувати структурами, силами та засобами МПЗ).

Суб’єктний компонент включає здатність організатора МПЗ до самооцінювання й усвідомлення власного рівня професійної компетентності, своїх професійних якостей, власної діяльності та себе як суб'єкта професійної діяльності.

Основні ознаки суб’єктного розвитку та саморозвитку слухача такі: цілісний і найвищою мірою усвідомлений образ самого себе в специфічній військово-професійній діяльності, для якого характерні оригінальність, неповторність та узгодженість елементів; ідентичність слухача як особистості в іншомовному соціокультурному, військово-професійному та фаховому середовищі; здатність бути насамперед самим собою та протистояти руйнівним впливам іншомовного соціокультурного середовища і деформаційним впливам професійної діяльності; здатність передбачувати внутрішні і зовнішні небезпеки професійної діяльності та моделювати оптимальний варіант їх подолання» [12, с. 9].

Науковці вважають, що «самооцінка власної діяльності - це здатність майбутнього фахівця оцінювати власні дії i результати діяльності та співставляти їх 3 правилами, нормами, стандартами. Під самооцінкою розуміють компонент самосвідомості, який включає оцінку особистістю самої себе, своїх здібностей, моральних якостей та вчинків» [13, с. 332].

Оскільки, професійна компетентність організаторів МПЗ розглядається нами як складова професійно-педагогічної компетентності, то зміст іiі 
зумовлюється особливостями професійної діяльності офіцера-вихователя (педагога), іiі суспільною значимістю, творчим характером і спрямованістю на вдосконалення педагогічної діяльності, розвиток професійного потенціалу офіцера структур МПЗ. Цю компетентність розглядаємо як інтегральну якість, що являє собою сукупність різних якостей, які характеризують здатність i готовність офіцера-організатора МПЗ ефективно вирішувати професійні завдання, зумовлені його службовими обов'язками.

Таким чином, запропоновані нами структурні та змістовні компоненти професійної компетентності організаторів МПЗ відображають зміст, особливості та напрями іiї розвитку у системі післядипломної освіти. Це дає можливість переосмислити, вдосконалити, скоординувати його професійнопедагогічну діяльність, підвищити рівень підготовки компетентних та соціально затребуваних організаторів МПЗ.

Перспективні напрями подальших наукових пошуків: обгрунтування організаційно-педагогічних умов розвитку професійної компетентності організаторів МПЗ на етапі оперативно-тактичної підготовки.

\section{ЛІТЕРАТУРА}

1. Про затвердження переліку галузей знань і спеціальностей, за якими здійснюється підготовка здобувачів вищої освіти : Постанова Кабінету Міністрів України від 29 квітня 2015 p. № 266. URL: http://zakon3.rada.gov.ua/laws/show/266-2015-п (Дата звернення: 15.03.2019 p.).

2. Про особливості запровадження переліку галузей знань і спеціальностей, за якими здійснюється підготовка здобувачів вищої освіти, затвердженого постановою Кабінету Міністрів України від 29 квітня 2015 року № 266 : затв. наказом Міністра освіти і науки України від 06.11.2015 №1151. URL: http://zakon5.rada.gov.ua/laws/show/z1460-15 (Дата звернення: 15.03 .2019 р.).

3. Про освіту : Закон України від 05.09.2017 р. №2145-VIII. Відомості Верховної Ради України. 2017. №38-39. 380 с.

4. Ягупов В.В. Військове виховання: історія, теорія та методика : навч. посіб. Київ : ВПЦ “Київський університет”, 2002.567 с.

5. Словарь иностранных слов / под ред. И. В. Лехина и др. ; гл. редактор Л. С. Шаумян. Москва : Сов. энциклопедия, 1964. 784 с.

6. Словник іншомовних слів / уклад. С.М. Морозов, Л.М. Шкарапута. Київ: Наукова думка, 2000. $680 \mathrm{c}$.

7. Словник української мови. Т. 4. Київ: Наукова думка, 2012. 568 с.

8. Зязюн І. А., Крамущенко Л. В., Кривонос І.Ф. Педагогічна майстерність : Підручник. Київ : Вища школа, 1997. 349 с.

9. Свистун В.І. Зміст поняття «компетентність» у контексті професійної підготовки фахівців як управлінців. Науковий вісник Національного університету. 2005. № 88. С. 180189.

10. Ягупов В.В, Свистун М.А. Управлінська культура і компетентність керівників як системна психолого-педагогічна проблема. Збірник наукових пращь Національної академії Державної прикордонної служби України : педагогічні та психологічні науки. наукове видання. Хмельницький : Вид-во НАДПСУ, 2013. № 4(69). С. 291-301.

11. В.М.Вилко, В. М. Грицюк， В.Г. Дикун. Морально-психологічне забезпечення у ЗС України : підручник: у 2 ч. Ч.І / за аг. ред.. В. В. Стасюка. Киӥв : НУОУ, 2012. 464 с.

12. Ягупов В.В. Психолого-педагогічні засади розвитку професійної суб'єктності у майбутніх магістрів військового управління в системі післядипломної освіти. Військова освіта : зб. наук. праць. Київ, 2008. № 22. С. 3-12 
13. Психологический словарь / под ред. В.В. Давыдова, А.В. Запорожца, Б.Ф. Ломова и др.; Москва: Педагогика, 1983. 448 с.

\section{REFERENCES}

1. Pro zatverdzhennia pereliku haluzei znan i spetsialnostei, za yakymy zdiisniuietsia pidhotovka zdobuvachiv vyshchoi osvity: Postanova Kabinetu Ministriv Ukrainy vid 29 kvitnia 2015 r. [On the approval of the list of branches of knowledge and specialties under which the training of applicants for higher education is carried out] № 266 . URL: http://zakon3.rada.gov.ua/laws/show/266-2015-p (Data zvernennia: 15.03.2019 r.). (in Ukrainian).

2. Pro osoblyvosti zaprovadzhennia pereliku haluzei znan i spetsialnostei, za yakymy zdiisniuietsia pidhotovka zdobuvachiv vyshchoi osvity, zatverdzhenoho postanovoiu Kabinetu Ministriv Ukrainy vid 29 kvitnia 2015 roku [On the peculiarities of the introduction of a list of branches of knowledge and specialties under which the training of higher education graduates is approved]. URL: http://zakon5.rada.gov.ua/laws/show/z1460-15 (Data zvernennia: 15.03.2019 r.). (in Ukrainian)

3. Zakon Ukrainy "Pro osvitu" [The Law of Ukraine "On the education"]. "Vidomosti Verkhovnoi Rady Ukrainy”, 05.09.2017 r. (in Ukrainian).

4. Iahupov V.V. (2002) Viiskove vykhovannia: istoriia, teoriia ta metodyka [Military education: history, theory and methodology]. K.: VPTs "Kyivskyi universytet". (in Ukrainian).

5. Slovar inostrannyih slov (1964) [Dictionary of foreign words]/ pod red. I. V. Lehina i dr.; gl. redaktor L. S. Shaumyan. Moskva: Sov. entsiklopediya. (in Russian).

6. Slovnyk inshomovnykh sliv (2000) [Dictionary of foreign words] / uklad. S.M. Morozov, L.M. Shkaraputa. K.: Naukova dumka. (in Ukrainian).

7. Slovnyk ukrainskoi movy (2012) [Dictionary of the Ukrainian language]. K.: Naukova dumka, 4. (in Ukrainian).

8. Ziazun, I. A., Kramushchenko, L. V., Kryvonos, I. F. (2004). Pedahohichna maisternist [Pedagogical skill]. K.: Vyshcha shk. 9 (in Ukrainian).

9. Svystun V.I. (2005) Zmist poniattia «kompetentnist» u konteksti profesiinoi pidhotovky fakhivtsiv yak upravlintsiv [The content of the concept of "competence" in the context of professional training of specialists as managers]. Naukovyi visnyk Natsionalnoho universytetu, 88, 180-189. (in Ukrainian).

10. Iahupov V.V, Svystun M.A. (2013) Upravlinska kultura i kompetentnist kerivnykiv yak systemna psykholoho-pedahohichna problema [Management culture and competence of managers as a systemic psychological and pedagogical problem]. Zbirnyk naukovykh prats Natsionalnoi akademii Derzhavnoi prykordonnoi sluzhby Ukrainy: pedahohichni ta psykholohichni nauky. naukove vydannia. Khmelnytskyi: Vyd-vo NADPSU, 4(69), 291-301.

11. Vylko, V.M., Hrytsiuk, V.M., Dykun, V.G. (2012). Moralno-psykholohichne zabezpechennia u ZS Ukrainy [Moral-psychological support in the Armed Forces of Ukraine]: pidruchnyk: u 2 ch. Ch.I / za red.V. V. Stasiuka. K.: NUOU. (in Ukrainian).

12. Iahupov, V.V. (2008) Psykholoho-pedahohichni zasady rozvytku profesiinoi subiektnosti $\mathrm{u}$ maibutnikh mahistriv viiskovoho upravlinnia v systemi pisliadyplomnoi osvity [Psychological and pedagogical principles of development of professional subjectivity in future masters of military management in the system of postgraduate education]. Viiskova osvita: zb. nauk. prats. K., 22, 3-12. (in Ukrainian).

13. Psihologicheskiy slovar (1983) [Psychological dictionary]/ pod red. V.V. Davyidova, A.V. Zaporozhtsa, B.F. Lomova i dr.; Moskva: Pedagogika. (in Russian).

\section{РЕЗЮМЕ}




\title{
Профессиональная компетентность организаторов морально-психологическое обеспечение: понятие, содержание и структура
}

В статье рассмотрены вопросы содержания профессиональной компетентности организатора морально-психологического обеспечения. Выяснено сущность ключевых понятий "содержание" и "структура", определены и научно обоснованы основные компоненты профессиональной компетентности, а именно следующие: ценностномотивационный, содержательный, деятельностный и субъектный. Их содержательное наполнение включает иенности, мотивы, интересы и потребности; отражает систему компетентно ориентировочных знаний; определяет пять групп взаимосвязанных способностей - гностические, проектировочные, конструктивные, коммуникативные, организаторские; розкривто систему профессионально важных качеств.

Ключевые слова: морально-психологическое обеспечение; профессиональная компетентность; организаторы морально-психологического обеспечения; ценности; мотивация; мотивы; интересы; потребности; профессионально важные качества; знания; способности.

\section{SUMMARY}

\author{
Serhii Nekhaienko \\ The National Defence University of Ukraine \\ named after Ivan Cherniakhovskyi
}

\section{Professional Competence of Moral-Psychological Support Organizers: Concept, Content and Structure}

Introduction. The training and manning of the Armed Forces $(A F)$ of Ukraine by officers of the structures of moral and psychological support (MPS) is now one of the most important and complex problems of military education. The organizer of MPS is a specialist who deals with educational and pedagogical work and psychological work in the troops. However, the problem of the professional competence of the officers-organizers of the MPS in scientific developments has not yet been identified.

Purpose. The goal of the article is to substantiate the professional competence of the organizers of MPS.

Methods. The author used general scientific theoretical (analysis, synthesis, generalization, explanation, classification), as well as system methods have been applied.

Results. The issue of the content of the professional competence of the organizer of MPShas been considered. The essence of key concepts "content" and "structure" is revealed, system of professionally important qualities is revealed.

Originality. The basic components of professional competence have been determined: valuemotivational, content, activity and subject. Five groups of interrelated abilities have been definedgnostic, design, constructive, communicative, organizational.

Conclusion. The proposed structural and content components of the professional competence of the organizers of the MPS reflect the content, features and directions of its development in the system of postgraduate education.

Perspective directions of further scientific researches: substantiation of organizational and pedagogical conditions of organizers' of MPS professional competence developmentat the stage of operational tactical preparation.

Key words: moral and psychological suppor; professional competence; organizers of moral and psychological support; values; motivation; motives; interests; needs; professionally important qualities; knowledge; ability. 